\title{
Nuclear Weapons in Europe
}

by our Washington Correspondent

A RARE glimpse of the extent and nature of the nuclear umbrella that the United States has erected over Europe is provided in a report prepared by staff members of the Senate Foreign Relations Committee. It indicates, among other things, that as many as 7,000 nuclear warheads are stockpiled in more than 100 special ammunition sites throughout Europe and, although all the weapons are in United States custody, about two-thirds of them are for use by European forces. Some of the weapons are constantly loaded, ready to be unleashed on command.

The report has been heavily censored by the Department of Defense and it is tantalisingly devoid of detail. Nevertheless, it lifts a fraction of the veil of secrecy that surrounds European nuclear defence planning and it brings together -and confers official status on-information which has previously appeared unofficially in the public record. It also emphasises the extent to which Europe is dependent on the United States for its defence.

Although delivery systems capable of carrying nuclear weapons were deployed by the United States in Europe during the 1950s, warheads were not stockpiled until President Eisenhower formally proposed the idea at a NATO Heads of Government meeting in 1957. Since then, the buildup of American nuclear weapons in European bases has been governed by a set of bilateral agreements between the United States and individual European governments. One of the agreements provides that the location of storage sites is to be determined by the NATO Supreme Allied Commander in Europe (SACEUR) who is also commander in chief of American forces in Europe--in agreement with United States military authorities nd the government of the country concetned. The agreements also specify that the weapons will remain in the custody of United States personnel, and that the 'user country' will pay the costs of stockpiling them.

The bilateral agreements are broad and they do not identify individual nuclear weapons systems. In fact, the Senate committee report states that it was not until 1967-a full ten years after stockpiling began-that the United States finally agreed to provide Euro- pean governments with details of the nuclear weapons stockpiled in their territory or stored elsewhere for use of their troops. (That revelation begs the question of how NATO managed to carry out sensible defence planning without knowing the nature of the weapons that the United States had installed in Europe.)

Robert S. McNamara, Secretary of Defense, announced in 1966 that there were then some 7,000 nuclear warheads stockpiled in Europe, a figure which the report notes "was the first, last and only official revelation regarding the size and disposition of the Amcrican nuclear armory in Europe". The total has since fluctuated and the present level has been deleted from the report, but $80 \%$ of the land-based warheads are for tactical weapons which can be used for offence or defence and the rest are purely defensive.

The warheads are stored in special igloos, in sites surrounded by double fences which are floodlit at night. Some of the weapons, including a proportion of those for use by European forces, are always maintained on what is termed quick reaction alert, ready to be fired as soon as the order is given. The proportion of the total nuclear force which is ready to be unleashed depends on the general state of alert in the NATO forces.

An agreement drawn up by NATO members in 1969 provides for consultation among member governments before nuclear weapons are used in Europe. According to the Senate report, it would work like this. A request for the use of nuclear weapons in the defence of NATO, which comes from either a member government or from a major NATO commander, or any possibility that a nuclear power may use nuclear weapons to defend NATO, will be communicated immediately to all NATO

\section{RESEARCH SPENDING}

\section{Buffelle Forecust of Increase}

by our Washington Correspondent Estimating the amount of money that will be spent on research and development in 1974 is a risky business, particularly in the light of the great uncertainties in the economic outlook. Nevertheless, according to the annual forecast of the Battelle-Columbus Laboratories, the total amount to be spent on research and development in the United States next year is expected to reach about $\$ 32,400$ million-an increase of some $\$ 2,300$ million over this year's expenditure. The Battelle forecast is $\mu$-rhaps the most widely expected of all the exercises in crystal-ball gazing that are carried out in the United States to predict funding for research and development.

Although the expected increase would be mostly swallowed up by inflationwhich is reckoned to be running at about $5 \%$ for research and development costs - it would nevertheless, represent a modest growth in purchasing power. Industry is expected to provide a relatively large increase in research funds, and support from the Federal Government is also expected to grow, according to the report.
Battelle acknowledges, however, that the forecast could be upset by energy shortages and other factors. On the one hand, if the energy crisis leads to widespread recession, industrial research and development could be hard hit. But, on the other, the energy crisis is likely to stimulate increased research and development on energy production and conservation.

The forecast sees the Federal Government providing about $\$ 16,800$ million, industry more than $\$ 13,700$ million, universities and colleges about $\$ 1,500$ million and non-profit institutions about $\$ 480$ million. Industry is therefore expected to provide about $42 \%$ of the total research and development funding next year, compared with $31 \%$ ten years ago. But the increases will not come from every industrial sector, for the forecast predicts that four industrial groups-food manufacturers, chemical companies, instrument makers and producers of electrical machinery-will increase their research and development funding at a rate greater than the rate of inflation. Expenditures by other industry groups will probably not even keep pace with inflation. 
governments and to the Defense Planning Committee (a top level committee consisting of all NATO members except France). The views of the individual governments and of the Defense Planning Committee would then be transmitted to the nuclear power concerned. In other words, the Supreme Allied Commander in Europe would "not be permitted to use nuclear weapons unless there were consultations with NATO member governments directly and with NATO itself".

In the final analysis, however, only the President of the United States or, for British nuclear weapons, the British Prime Minister, can authorise the release of nuclear weapons. Thus Presidential approval would be required before any use of United States nuclear weapons by NATO forces.

The Senate report outlines general NATO strategy with respect to both conventional and nuclear forces, the basic elements of which are "nuclear deterrence, forward defense and flexible response". Should deterrence fail, there are three levels of military response open to allied forces. "The first is direct defense-that is, defeating the enemy on the level he chooses to fight, a concept which includes the use of such available nuclear weapons as may be authorised". The second level of response would be "deliberately raising, but where possible controlling, the scope and intensity of combat, making cost and risk disproportionate to the aggressor's objectives and the threat of nuclear response progressively more imminent". The final response would be "massive nuclear strikes against the total nuclear threat, other military targets and urban industrial targets". The ultimate general nuclear response could, however, be carried out only in conjunction with the United States Joint Chiefs of Staff plan for widespread synchronised use of United States nuclear weapons. "Accordingly", the report notes, "responsibility for carrying out NATO's general nuclear response falls on US strategic forces based outside Europe".

\section{EPA}

\section{Appearing Objective}

by our Washington Correspondent

Mr Russell Train, the new Administrator of the United States Environmental Protection Agency (EPA), has decided to cut off a subsidy that the agency provides to an industrial research organisation because of public allegations that the subsidy compromises the EPA's regulation of automobile pollution. The organisation concerned is the Coordinating Research Council-Air Pollution Research Advisory Committee
(CRC-APRAC), a research organisation supported by the automobile industry, the oil industry and the EPA. It has sponsored some of the key research on which many emission control regulations have been based.

The decision to sever ties between the EPA and CRC-APRAC was based on a review conducted by $\mathrm{Mr}$ Train shortly after he became administrator of the agency. He explained in a letter to Mr M. K. McLeod, director of CRC-APRAC, that although he is entirely satisfied that the organisation's work has been objective and free from bias, "not only the fact of objectivity but also the appearance of objectivity must be considered when it comes to evaluating continued EPA participation in this activity".

CRC-APRAC receives three-quarters of its money from the American Petroleum Institute and the Motor Vehicles Manufacturing Association, both of which are industrial organisations, and the rest from the EPA. It funds research on the effects on health of automobile emissions, on emission control technology and on vehicle testing.

The chief criticisms of the agency's ties with CRC-APRAC have come from Senator Edmund S. Muskie, Chairman of the Subcommittee on Air and Water Pollution, and the chief sponsor of pollution control measures in the Senate. He has charged that the organisation's advisory committee, on which representatives of the automobile and oil industries predominate, decides, without outside advice, what research should be undertaken; that the research is then monitored by panels which are also dominated by industry representatives; and that the results eventually wind up as the basis for regulations vitally affecting the industries concerned.

As evidence of conflict of interest in CRC-APRAC, Muskie published an internal EPA memorandum in the Congressional Record last week which discusses the motor industry's attitudes to the EPA's programme to control emissions from heavy-duty diesel engines. According to the memorandum, an official of Cummins Engine, one of the two largest manufacturers of diesel engines in the United States, said in a discussion that the CRC-APRAC programme to develop new test procedures for heavy-duty engines/vehicles was the most "effective coup that the industry has pulled off on EPA" as it commits the EPA to a long and complicated project which could postpone instituting controls for heavy-duty engines for many years.

In addition to severing its formal ties with CRC-APRAC, the EPA has decided to take over the management and funding of three projects which are now being carried out under the organisation's auspices.

\section{COAL}

\section{Aggreguted Waste}

DAMAGING though the miners' overtime ban may be to the National Coal Board (NCB) there is one section of the board that has its problems temporarily eased. The Minestone Executive is responsible for the 50 million tons of spoil that emerge from the ground each year along with the coal. While the overtime ban is on, the quantities are at least a little smaller.

With the increasing mechanisation of the coal industry the quantities of waste produced have risen sharply. Machine mining often takes parts of the roof and floor away at the same time as the coal and this extra waste travels up to the surface.

But attempts to do anything with the shale that was accumulating in massive tips in the mining areas are relatively recent. Only in the past fifteen years has a serious effort been made. It is estimated currently that the coal board has in the region of 3,000 million tons of spoil lying around Britain.

Now that local authorities have tightened up on their planning procedures new tips are hard to start and old tips are frowned on, so the NCB has the job of tidying up the past and preventing desecration in the future.

Finding uses for the shale has never been easy. Several million tons have been used as fill for motorways. About half a million tons a year have been turned into bricks by the Scottish and the Midland Brick Companies, and some spoil has been turned into a base matrix for the extremely tough but very expensive Guyana bauxites. This mix has a high skid resistance and has been put on Britain's crossroads particularly in the Greater London Council area. But, beneficial though this use is, the tonnages involved are relatively small.

With the large motorway programme in the coalfield areas coming to an end the demand for spoil as a motorway fill is decreasing. Although major road works will still need the spoil, the sharper bends and steeper hills allowed on main roads will cut the demand.

But with the oil shortage certain to increase the cost of transport, colliery spoil could benefit. Transport is the highest part of the cost of any shale. With the coal fields in the centre and in the north of Britain it could become economically attractive to use closer, although less satisfactory, shales from collieries than to go further afield for a higher quality stone.

The best future use for shale may lie in the aggregates business. The Verney Committee, set up by the Department of the Environment, produced a preliminary report recently in which it stated that current demand for aggregates is around 220 million tonnes a 